Biljana B. Radić-Bojanić University of Novi Sad Faculty of Philosophy Department of English Studies
УДК: $371.3:: 81 ' 243$

https://doi.org/10.18485/uzdanica.2020.17.2.1

Оригинални научни рад Примљен: 30. септембар 2020. Прихваћен: 30. новембар 2020.

\title{
THE COMMUNICATIVE APPROACH IN FOREIGN LANGUAGE TEACHING ${ }^{1}$
}

\begin{abstract}
The Communicative Approach in foreign language learning has occurred in a sociohistorical context when larger numbers of people were granted the possibility to learn foreign languages and it has relied on the concept of communicative competence whose main focus was fluency. This radical change in the teaching paradigm meant a step away from the dominant Grammar-Translation Method, but the Communicative Approach also differed from other more similar methods in the field of foreign language learning (e.g. the Audiolingual Method and the Natural Approach). This paper offers a description and a critical assessment of the linguistic framework upon which the Communicative Approach was based, but it also lays out its main aims and principles that have changed over time. Finally, the paper also discusses unresolved issues surrounding the Communicative Approach, which concern the treatment of grammar and students' varying cultural backgrounds that collide with its basic principles.
\end{abstract}

Keywords: the Communicative Approach, communicative competence, fluency, accuracy, learner-centred, teacher-centred, culture.

\section{INTRODUCTION}

When in 1972 Hymes wrote his famous paper on communicative competence, as a response to Chomsky's view of competence and performance, this was an important stepping stone for applied linguists, who advocated for a communicative view of the teaching process. The reason behind this was that "the idea of using the concept of idealized, purely linguistic competence as a theoretical ground of the methodology for learning, teaching and testing languages" (Bagarić, Mihaljević Djigunović 2007: 95) seemed untenable and unrealistic, whereas Hymes' (1972) communicative competence did not include only grammatical competence, but

\footnotetext{
${ }^{1}$ The paper is the result of research conducted within project no. 01600 funded by the Ministry of Education, Science and Technological Development of the Republic of Serbia.
}

radic.bojanic@ff.uns.ac.rs 
also the ability to use language in a variety of communicative situations. In the 1980's Canale and Swain (1980) and Canale (1983) further developed this notion and described it as a system of various types of knowledge and skills necessary for successful communication, claiming that communicative competence is composed of grammatical competence, sociolinguistic competence and strategic competence (Canale, Swain 1980: 27).

If this change in the paradigm is observed in a wider sociopolitical and historical context, it is clear why it propelled the communicative approach to foreign language teaching. Namely, after the end of the Second World War fundamental changes occurred in all spheres of life, especially in the global economy. More and more people travelled to foreign countries as travel was more affordable, which meant an increased need for people to start learning foreign languages. Previously, learning a second language had been intended only for the elite, those special, select few who attended prestige schools and could afford private tutors as well as subsequent foreign travels, when they actually spoke the foreign language. However, in the 1960's and 1970's, in an attempt to provide secondary education for all, this privilege of learning a foreign language was suddenly extended to larger portions of the population. Therefore, in order to train people to be able to use a foreign language to a certain extent on foreign travels, relying on the concept of communicative competence scholars developed the approach they called Communicative Language Teaching (CLT), whose main purpose was to focus learners much more on fluency than on accuracy.

This paper is an attempt to describe and critically assess communicative language teaching within the larger framework of foreign language teaching, with respect to its main aims and principles, in comparison with other methods and approaches, and in view of different unresolved issues that accompany it.

\section{COMMUNICATIVE LANGUAGE TEACHING: FOUNDATIONS}

In the previously described sociohistorical context, as Richards (2006: 1) explains, the need for fluency in English has been increasing, thus creating a need for English teachers all around the globe. Regardless of the age of learners, the primary goal was to become fluent in English, which meant that theoreticians and practitioners embarked on a quest to find an approach which would achieve this result. In the same way as parents wanted their children to learn the language, employers also wanted employees who would be fluent and fairly proficient in English, which was "a prerequisite for success and advancement in many fields of employment in today's world" (Richards 2006: 1). Such a demand for a good methodology came at a time when, as previously said, linguists promoted the idea of communicative 
competence, which engendered a set of principles and methods known today as Communicative Language Teaching.

Since communicative "competence is defined in terms of the expression, interpretation, and negotiation of meaning and looks to both psycholinguistic and sociocultural perspectives in second language acquisition (SLA) research to account for its development" (Savignon 2017: 1), it implies that a competent speaker has a command over the language, grammar, and vocabulary and can use it adequately in various situations. In the context of English language teaching, this competence is developed through the proper application of CLT, which means that learners have conquered some of the important milestones that constitute a proficient speaker of the English language. Fluent speakers should know how to use the language for various purposes and adapt it based on the setting, including formal and informal speech, as well as differentiate between spoken and written text and maintain communication (Richards 2006: 3, 36).

It can be deduced that a vital characteristic of CLT is fluency, which means that speakers can easily use language whenever they participate in or maintain an understandable and meaningful interaction, despite limitations in their communicative competence (Richards 2006: 14). On the opposite side of fluency is accuracy, the goal of the Grammar-Translation Method, which strives for precision in the use of the language, very often at the cost of fluency. One way to develop fluency as an essential feature of CLT is to organize real-life exercises, where learners have to maintain an improvised conversation without breaking the communication for any reason, even at the expense of accuracy. Richards (2006: 14) explains that activities focusing on fluency should "reflect natural use of language, focus on achieving communication, require meaningful use of language, require the use of communication strategies, produce language that may not be predictable, and seek to link language use to context".

For learners to improve their communicative competence and skills the syllabus should identify some of the aspects of the foreign language that learners should cover in the learning process. Van Ek and Alexander (1980) offer the following proposals:

- learners should know what is their goal when learning the given language;

- learners need to know where they will use the language they are learning;

- learners have to know what role they will have after learning the language (e.g. a travel agent, a salesperson, etc.);

- learners should expect some communicative events where they will use the language, whether professionally (e.g. participate in a business meeting) or in everyday situations (e.g. phone calls); 
- learners should be aware of language functions that will be a part of the communicative events (e.g. giving instructions);

- some notions are necessary to talk about certain topics like finance or medicine;

- learners should be familiar with discourse and rhetorical skills like storytelling;

- learners of English need to expect certain levels of variety when it comes to the dialects such as American, Australian and British English;

- grammatical content is also important for learners;

- learners need to work on their vocabulary.

These proposals were a basis upon which courses could be developed and syllabi created, so the idea was to construct lessons that would cover only portions or units, each of which would correspond to a component of the learner's need and would be systematically related to all other portions (Van Ek, Alexander 1980). Such syllabi would promote the necessity to teach useful communicative skills when it comes to learning a second language and the identification of learners' communicative needs would provide a basis for curriculum design (Van Ek 1975). The increase in the number of non-institutional learners called for alterations in the syllabus as there was a need to make it fit for the needs of adults. For this reason applied linguists started coming up with new unusual ideas for new methods of learning. CLT was simply an answer to all the inadequacies of the formal teaching method. What worked so far with other languages, such as Latin, could not be appropriate for modern languages used in a variety of contexts and for a variety of purposes. Memorization and endless repetition pattern were not applicable when it came to the learners who had no need or time to gain an in-depth knowledge of the second language. In the past syllabi were formal, structured, highly focused on grammar and dealt with familiar terms such as nouns, verbs, adjectives, tenses, etc. However, this type of syllabus was only useful to learners interested in gaining a thorough knowledge of the foreign language and thus impractical for the new type of learners.

Over time it became apparent that CLT was not a structured method of teaching, but a wide array of principles and ideas, an approach (Richards, Rogers 1986). More precisely, CLT as an approach defined a broad language teaching philosophy, which could then be interpreted and applied in a variety of different ways in the classroom (Rogers 2001). Keeping that in mind, in its early development teachers could create a mix of traditional classroom activities, using both grammar and communicative exercises as a guide for on open conversation. It was argued that a classroom should provide lifelike opportunities to rehearse possible scenarios which would help learners in real-life situations. Even though audiovisual and other structural methods already introduced speaking and listening activities, 
they did not included role-playing as a new exercise in an attempt to simulate a real-life experience, unlike the Communicative Approach.

According to Jacob and Farrell (2003), the shift in language teaching has created eight changes in the approach to second language education:

- Learner Autonomy means that learners can choose every aspect of their learning experience, for example, self-assessment;

- Social Nature of Learning shows that learning is a social activity employing cooperative learning;

- Curricular integration means that English is linked to other subjects in the curriculum (examples can be found in projects which require students to seek answers outside of the classroom);

- Focus on meaning is the search for meaning as the base of learning a foreign language;

- Diversity teaches that teachers need to understand that all learners learn differently;

- Thinking skills are a part of a language, i.e. language should serve for critical, creative thinking. Language is not learned for the sake of learning, but for learners to be able to apply it outside of the classroom;

- Alternative Assessment offers other types of assessments other than multiple choice or fill-in-the-blanks, such as fluency, social appropriacy and thinking;

- Teachers as co-learners means that teachers constantly try different approaches, exercises, and processes to find out what works in the classroom, i.e. learning through doing.

The methods and approaches currently applied in the foreign language classroom draw from the traditional approach and connect it with the Communicative Approach, thus taking the best from both worlds. One such example is teaching grammar as a part of a communicative task and not in an isolated instance. Some activities inspire both deductive and inductive learning of grammar, at the same time creating a need for the communication of meaning while performing role-play or sharing information. In such a way learners are able to realize that grammar is not an isolated system of rules, but a functional structure with meaning that is selected and modified according to the given situation.

\section{COMMUNICATIVE LANGUAGE TEACHING AND OTHER METHODS}

In order to see how Communicative Language Teaching differs from previous methods in foreign language teaching and in order to illustrate what kinds of 
benefits it has brought to this field of education, a brief comparison will be made with other dominant methods from the previous period.

The first is the Grammar-Translation Method, which had been present in the educational process for several centuries. It was primarily used in the teaching of classical languages, Greek and Latin, whereby students were required to learn grammatical rules, memorize words and definitions, and use pre-written sentences and dialogues (Chang 2011). Subsequently, when other modern languages became interesting to people who travelled around Europe and the world, the only option for instruction was this method. Its principles and methodology were mapped onto teaching French, German or any other modern language, which meant that despite the fact that learners could communicate in these languages orally because they were living languages, they still had to copy and translate endless sections of text, learn grammatical rules by heart, etc.

In comparison with this method, where learners focused on grammar, memorized words and definitions, and used pre-written dialogues, CLT was based on improvised practice and natural language use with an emphasis on speaking. In addition, while the Grammar-Translation Method aimed at accuracy, CLT aimed at fluency. In other words, in the past, learning a new language was considered to be very formal, with a strong focus on mastering grammar or building grammatical competence, thus creating a feeling of mechanized learning. The emphasis was on producing correct answers and not on learning through making mistakes, which were avoided by all means. That was done by making sure the dialogues were memorized. CLT, however, has a different approach. Open dialogue is based on improvisation and is a fertile ground for errors. The teacher is no longer in absolute control of the activities in the classroom and should not jump at every mistake and correct it. CLT has shone an entirely new, distinct light on the idea of learning a new, second language showing that there are processes that play an important role in the development of communicative competence, such as interactions with native users of the language in question, experimenting with the meaning of words and, already mentioned, an open, creative dialogue which is entirely improvised.

However, even today, when the Communicative Approach is well established and widespread, a large number of teachers still choose to maintain the use of the Grammar-Translation Method. Perhaps some of the reasons lie in the fact that it is relatively easy to test grammar with a test or translation, and not many standardized tests focus on communication. Also, teachers often opt for a combination of these two approaches, e.g. they teach grammar deductively, practice it through controlled tasks and later let students practice the use of new grammatical units in communicative tasks.

Another influential method, especially in mid- $20^{\text {th }}$ century, was the Audiolingual Method. Its goal was to develop a functional communicative competence, which was essentially very similar to the goal of CLT. However, there are some stark differences between the two approaches. The first one is in the types of 
knowledge they were trying to build up: the Audiolingual Method pursued memorization so learners are able to create a base for further knowledge, whereas CLT, on the other hand, aimed to achieve the same by putting learners in realistic communicative situations, undermining the old-fashioned, structured language tasks of the Audiolingual Method. More precisely, the Audiolingual Method relied on behaviourism and its proponents believed that the automated cycle of Presentation-Practice-Production would in time develop autonomy and fluency in learners (Richards 2006: 8). However, this insistence on using a correct model of sentences, which were then repeated through drill without much explanation and without any instruction in grammar, did not produce satisfactory results. Namely, through this approach learners did not achieve any communicative competence, i.e. they were not able to use the foreign language in authentic situations because the possibilities of different sentence combinations were endless in real life. Littlewood (1981) emphasizes that, on the other hand, one of the most distinctive features of CLT is that it pays systematic attention to functional, as well as structural aspects of the foreign language, combining these into a more fully communicative view.

In comparison with the Audiolingual Method, in CLT the roles of teachers and learners also underwent substantial changes. Namely, a shift occurred from the focus on the teacher to the focus on the learner, whereby the teacher became a guide and a facilitator and the learners carried most of the activities: listening to each other during group work, doing tasks individually, becoming responsible for their own progress.

The third approach that could be compared to CLT is the Natural Approach, whose main principles are based on exposing students to comprehensible input. In essence, the focus in this approach is not on grammar, but on a variety of texts that learners are exposed to. The idea is that students listen or read, i.e. only activate their perceptive skills, while there is no pressure to produce language. A similarity with CLT lies in the exposure to authentic language and a learning situation where learners can replicate the foreign language in a fun activity, but, as Lightbown and Spada (2006: 176) note, there is no support for the hypothesis that language acquisition will take care of itself if second language learners simply focus on meaning in comprehensible input. More precisely, even though the Natural Approach does not put focus on grammar, pronunciation and error correction, learners still need guidance and practice to push them further, to start using language effectively and actively. Essentially, although it is not always vital to focus on grammar, it is also not enough to be exposed to an environment where the foreign language is used. On the contrary, practice is necessary as well as scaffolding, which are part of the gradual, structured approach promoted by CLT. 


\section{UNRESOLVED ISSUES IN COMMUNICATIVE LANGUAGE TEACHING}

The Communicative Approach demands a radical reform of foreign language teaching and has without a doubt created a great impact on both teachers and learners. Thanks to the Communicative Approach, learners' goals are better defined and more familiar, which is an improvement that helps teachers create meaningful activities that will, in turn, assist learners to achieve their objectives. Even though this comprehensive and innovative approach to foreign language teaching has a lot of strengths, especially in comparison with other methods, there are also several issues that still need to be resolved. Dörnyei (2009) discusses a variety of necessary revisions to the approach needed to be implemented, especially with reference to new findings in the field of psycholinguistics.

One of the burning issues is grammar (Al-Humaidi 2007), or better yet, the lack of knowledge about grammar when the learners only focus on the activities provided by the Communicative Approach. Al-Humaidi (2007) explains that CLT prioritizes meaning over grammatical rules, which may have negative consequences such as the lack of learners' awareness of important structures and rules. Despite the fact that the Grammar-Translation Method has been severely criticized precisely due to its extreme focus on grammar, this knowledge is crucial in any kind of more formal encounters with native speakers, especially in the business or academic context. There are multiple offered solutions, but most of them propose a balance between grammar learning, which is based on accuracy, and communication exercises that teach fluency.

The second issue tackles the relationship between doing and reflecting (cf. Dörnyei 2009: 34). What this means is that learners and teachers are encouraged to use language in simulated real-life exercise, but without much explanation. However, learners will hardly develop independence if they are unable to practice on their own or to develop their own strategies, all of which is difficult without explanations in their own mother tongue. In other words, fluency is emphasized at the expense of reflection and strategic competence.

Finally, as CLT attains the humanist view which sees language as an expression of personal meaning, and not that of a common culture, it retains a very Western style of thinking (Thornbury 2003). In that sense, it is not an adequate choice for the situations in which the teacher is still considered the head of the classroom and in which accuracy is valued over fluency, i.e. high power distance cultures (Neuliep 2009). The problem occurs when learners are required to communicate in class. Sano et al. (1984) have highlighted that their informants from Japan did not feel the need to use English, which made communicative competence a very distant concept for them. Studies focusing on other countries in Asia produced similar results, so Ellis (1994) found that in Vietnam class size, grammarbased examinations, and lack of exposure to authentic language disallowed the 
application of CLT. Burnaby and Sun's study (1989) of the Chinese educational context reached a similar conclusion and Larson-Freeman (1986) found that in Taiwan learners are not prone to mixing games and learning; instead, they prefer the Grammar-Translation Method and are used to asking the teacher questions to clarify elements that they have difficulties understanding. All these characteristics point to a teacher-centred approach, which is fundamentally different from the student-centred approach promoted by CLT.

\section{CONCLUSION}

The classroom of today is more than just a simulated learning environment for mastering a foreign language without ever truly talking to its speakers. On the contrary, in today's culture it is also a social environment where the participants learn the language that they have the opportunity to speak and use almost on daily basis. In the era when the world has become a global village, the Communicative Approach may appear as a natural transition from the old, structural method, focused primarily on form and grammar, into the logical, modern approach of acquiring a foreign language. Classes based on the communication between the students offer endless possibilities for planning interesting activities and, at the same time, they provide a possibility for teachers to raise the level of their students' communicative competence in a new and creative way.

Since the 1980's CLT has been mentioned numerous times, almost turning its name into a buzzword, and yet despite its widespread implementation it has been called into question due to its dubious role in covering a more uniform teaching method. From its birth, the CLT approach has had its basis in the notion of communicative competence as the goal in foreign language teaching and as such was prone to alterations as the understanding of foreign language learning changed. This has actually led to a realization that CLT cannot be a single set of rules or practices, but several principles upon which there is a preexisting general agreement. The application of these agreed-upon principles depends on the content, but also on the learners and their needs, age, level of knowledge of the second language, as well as the goal learning the foreign language.

It can be concluded that the Communicative Approach is adaptable and ever-changing, not a structured set of rules. As time passes CLT matures and its users are growing increasingly aware of its advantages, but also its limitations. This honest and critical view of such an approach always leads to its improvement, which necessarily intertwines theory and practice and feeds off the collaboration of diverse groups of experts. 


\section{REFERENCES}

Al-Humaidi (2007): M. Al-Humaidi, Communicative Language Teaching, King Saud University.

Bagarić, Mihaljević Djigunović (2007): V. Bagarić, J. Mihaljević Djigunović, Defining Communicative Competence, Metodika, 8/1, 94-103.

Burnaby, Sun (1989): B. Burnaby, Y. Sun, Chinese Teachers' Views Of Western Language Teaching: Context Informs Paradigm, TESOL Quarterly, 23, 219-238.

Canale (1983): M Canale, From Communicative Competence to Communicative Language Pedagogy, In: J. C. Richards, R. W. Schmidt (Eds.), Language and Communication, London: Longman, 2-27.

Canale, Swain (1980): M. Canale, M. Swain, Theoretical Bases of Communicative Approaches to Second Language Teaching and Testing, Applied Linguistics, 1, 1-47.

Chang (2011): S-C. Chang, A Contrastive Study of Grammar-Translation Method and Communicative Approach in Teaching English Grammar, English Language Teaching, 4(2), 13-24.

Dörnyei (2009): Z. Dörnyei, The 2010s CLT in the $21^{\text {st }}$ Century: The Principled Communicative Approach, Perspectives, 36(2), 33-43.

Ellis (1994): R. Ellis, The Study of Second Language Acquisition, Oxford: Oxford University Press.

Hymes (1972): D. Hymes, On Communicative Competence, In: J. B. Pride, J. Holmes (Eds.), Sociolinguistics, Harmondsworth: Penguin Books, 269-293.

Jacobs, Farrell (2003): G. M. Jacobs, T. S. C. Farrell, Understanding and Implementing the Communicative Language Teaching Paradigm, RELC Journal, 34(1), 5-30.

Larson-Freeman (1986): D. Larson-Freeman, Techniques and Principles in Language Teaching, Oxford: Oxford University Press.

Lightbown, Spada (2006): P. M. Lightbown, N. Spada, How Languages Are Learned, Oxford: Oxford University Press.

Littlewood (1981): W. Littlewood, Communicative Language Teaching, New York: Cambridge University Press.

Neuliep (2009): J. Neuliep, Intercultural Communication: A Contextual Approach, Thousand Oaks: Sage Publications.

Richards (2006): J. C. Richards, Communicative Language Teaching Today, Cambridge: Cambridge University Press.

Richards, Rodgers (1986): J. C. Richards, T. Rodgers, Approaches and Methods in Language Teaching, Cambridge: Cambridge University Press.

Rogers (2001): R. R. Rogers, Reflection in Higher Education: A Concept Analysis, Innovative Higher Education, 26, 37-57.

Sano, Takahashi, Yoneyama (1984): M. Sano, M. Takahashi, A. Yoneyama, Communicative Language Teaching and Local Needs, ELT Journal, 38(3), 170-177.

Savignon (2017): S. Savignon, Communicative Language Teaching: Linguistic Theory and Classroom Practice, In: S. Savignon (Ed.), Interpreting Communicative Language Teaching, New Haven: Yale University Press, 1-27. Press.

Thornbury (2003): S. Thornbury, How to Teach Grammar, Beijing: World Affairs 
Van Ek (1975): J. A. van Ek, The Threshold Level, Education and Culture, 28, $21-26$.

Van Ek, Alexander (1980): J. A. van Ek, L. G. Alexander, Threshold Level English in a European Unit/Credit System for Modern Language Learning by Adults, New York: Pergamon Press.

\author{
Биљана Б. Радић-Бојанић \\ Универзитет у Новом Саду \\ Филозофски факултет \\ Одсек за англистику
}

\title{
КОМУНИКАТИВНИ ПРИСТУП У НАСТАВИ СТРАНИХ ЈЕЗИКА
}

Резиме: Након Другог светског рата потреба да људи уче страни језик постајала је све већа, тј. настава страног језика више није била доступна само привилегованој богатој мањини. С друге стране, са ширењем наставе страних језика школе су углавном преузимале граматичко-преводни метод који се раније користио за учење грчког и латинског, што се у ситуацији кад је и деци и одраслима било потребно да комуницирају на страном језику показало крајње неадекватним. Истовремено у области теоријске лингвистике долази до помака у поимању језичког знања, па тако Хајмс уводи појам комуникативне компетенције, који се касније рашчлањује на граматичку, социолингвистичку и стратешку компетенцију.

Кад се посматра спој наставе страних језика и појма комуникативне компетенције, увиђа се да комуникативни приступ заговара течност у изражавању науштрб тачности, као и да се фокусира на значење, природност и аутентичност у учењу, на различитости у личностима ученика, те на развој критичког мишљења. У поређењу са другим методама у настави страних језика, увиђа се велика разлика између комуникативног и граматичко-преводног метода, али и неке сличности са аудио-лингвалним методом и природним приступом. Међутим, комуникативни приступ и аудио-лингвални метод се разликују по томе што се потоњи ослања на принципе бихејвиоризма и кроз дрил покушава да ученике научи страном језику.

С друге стране, природни приступ се ослања на разумљиви инпут без имало употребе матерњег језика, што у ствари може да у великој мери отежа процес учења и разумевања страног језика. Временом су идентификоване слабости у овом приступу настави страних језика и наставници су заједно са теоретичарима увидели да је потребна комб́нација разних метода и приступа, како оних који се фокусирају на форму, тако и оних који се фокусирају на садржај, да би ученици научили страни језик. Увођењем иновативних и креативних садржаја и вежби наставници добијају могућност да развијају комуникативну компетенцију својих ученика кроз овај еклектичан приступ који се прилагођава ученичким потребама, узрасту, нивоу знања и циљу учења страног језика.

Кључне речи: комуникативни приступ, комуникативна компетенција, течност, тачност, усмереност ка ученику, усмереност ка наставнику, култура. 